\title{
The Study of the Relationship between Leadership Style and Project Success
}

\author{
Juanjuan Jiang \\ School of Management, Guangdong University of Technology, Guangzhou, China
}

Access this article online

Website:

www.ajtp.us

Volume 1

Number 1/2014

Issue 1

DOI:

Licenced:

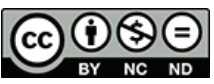

E-mail for correspondence:

983534367@qq.com

\section{ABSTRACT}

From three aspects of literatures: Leadership style, project success factors, and the match of leadership type and project type, this paper studied the relationship between leadership style and project success, and found that although leadership or manager is rarely included in the project success factors, it influences the performance of project through various patterns, like the collaboration of teamwork, management of source, communication with both followers and clients.

Keywords: Leadership style, Project success, Project management

Received: June 25, 2014

Accepted: June 27, 2014

Published: June 30, 2014

\section{Introduction}

Up to now, there are many theories of leadership style are available, like emotional intelligence, contingency, competency and so on. All of them claim that appropriate leadership style can benefit project success. This study aims to find the relationship between leadership style and project success. Three aspects of literatures were reviewed including leadership style, project success factors and the match of leadership type and project type. From the literature review, it was interesting to find that leadership was rarely considered by the critical success factors of the project. Turner and Muller (2005) contemplated that probably the project manager's neglect themselves or leadership is not covered in research. However, other reviews show that the effect of manager is critical to the project. By studying the mold built by Yang (2011), it is learnt that leadership influence the project success through teamwork. While some of the fifteen leadership competencies (Dulewicz and Higgs, 2003) are directly related to project success factors. So it is concluded that, in a certain project type, appropriate leadership can improve project success in two ways, both teamwork and direct impact. A simple system dynamic model was designed to show the relationships within project management. However, there were no researches done to prove this conclusion. Further study is needed.

\section{Methodology}

The aim of the study is to find that whether the project success is influenced by leadership style. To realize it, three objectives were set:

- To review literature of leadership style.

- To review literature related to project success factors and the their link with leadership style.

- To review literature about how leadership style influence project success.

- To find the correlation between leadership style and project success based literature review.

The main search techniques are Google scholar and Web of Science. The cross search facility provided by McClay Library was tried as well. Key words, project manager, leadership style, project success, competency school etc., or their combinations were applied to search useful literature. Firstly, the literature review of this topic written by Turner and Muller (2008) was read to learn the background information and find related articles in the reference in this paper. Secondly, articles related to leadership style were found are reviewed. The leadership as the core of the review, deep review was required, so very specific articles where there was only one leadership system were

This article is licensed under a Creative Commons Attribution-NonCommercial-NoDerivatives 4.0 International License. 
studied. The gathered valuable information was compared and tabulated. The same degree of review was also applied to relation part. While for success factors, only general knowledge was extracted from literatures.

After finishing the review, the information was analyzed to work out the link between leadership skills and good performance of skills. The sources of literature are listed in Table 1.

\section{Literature Review and Critical Analysis}

In this part, literature related to leadership style, project success and relationship between them are reviewed. And based on the review, analysis of the literature was made where it is valuable. Finally, personal view points were concluded from the literature review and analysis.

\section{The Development of Leadership Style}

In the past years, leadership has been explained in various ways, while the core concepts of all the definitions concerning the communication between project leaders and their subordinates (DuBrin 2004; Koontz and Weihrich, 1990). And leadership style is the term describing how the leader manages the project.

By now, Turner and Muller (2005) summarized six groups of leadership theories, which have been tabulated in Table 2 as well as their corresponding relationship with project type.

Table 1: Summary of literatures

\begin{tabular}{lc}
\hline Source & Number \\
\hline International Journal of Project Management & 4 \\
Project Management Journal & 3 \\
Journal of Organizational Change Management & 1 \\
Book & 10 \\
\hline
\end{tabular}

Before 1940s, people considered that leadership was owned by some certain people who were born to be leaders. This attitude was changed by the behavioral or styles theory. This theory identified six parameters to assess the leadership including (Turner and Muller 2005): concern on people, production, authority, participation of the decision-making for the team, decision-taking and the flexibility against rules. The leadership of this theory listed in Table 2 is identified based on the last three parameters (Turner 1999). The following theory, Contingency, its most significant contribution is the inception of concern for different circumstances, indicating the correlation of project type and leadership skill had been under consideration. One theory of contingency school, the path-goal theory (House 1971) even had introduced the environmental and subordinate factors to help select appropriate leadership styles. The visionary or charismatic school was concluded by studying leaders who successfully managed their companies through change. It can be found in Table 2 three leaderships have been identified. The transactional style manages a simple exchange of good performance of followers for the rewards from the leader (Wang et al., 2005). While when the project is out of plan, actions will be taken by the leader. Different from transactional style, the transformational leaders prefer to make use of his charisma to influence their subordinates.

The latest theories are the emotional intelligence school and competence school. For emotional intelligence, this theory distinguishes leaders by how they apply their emotional skills, rather than intellect, to deal with situations. Nineteen related components are identified and categorized into four factors (Goleman et al., 2002):

- Personal competencies

- Self-awareness

- $\quad$ Self-management

- Social competencies

- Social awareness

- Relationship management

Table 2: Summary of the development of leadership

\begin{tabular}{|c|c|c|c|c|}
\hline Theory & Time & Main idea & Leadership style & Relationship with project type \\
\hline Trait & $1930 s-1940 s$ & $\begin{array}{l}\text { Outstanding leaders are born with same } \\
\text { traits }\end{array}$ & Not defined & Not defined \\
\hline $\begin{array}{l}\text { Behavioral } \\
\text { or styles }\end{array}$ & $1940 s-1960 s$ & The leadership skills can be learned & $\begin{array}{l}\text { Laissez-fair } \\
\text { Democratic } \\
\text { Autocratic } \\
\text { Bureaucratic }\end{array}$ & Not defined \\
\hline Contingency & $1960 \mathrm{~s}$ & $\begin{array}{l}\text { The effectiveness of certain leadership } \\
\text { varies in different situations }\end{array}$ & $\begin{array}{l}\text { Directive } \\
\text { Supportive } \\
\text { Participative } \\
\text { Achievement-oriented }\end{array}$ & $\begin{array}{l}\text { The leadership should be selected } \\
\text { according to environmental and } \\
\text { subordinate factors }\end{array}$ \\
\hline $\begin{array}{l}\text { Visionary or } \\
\text { charismatic }\end{array}$ & $1980 s-1990 s$ & $\begin{array}{l}\text { The leadership styles are defined } \\
\text { according the concern of process and } \\
\text { relationships }\end{array}$ & $\begin{array}{l}\text { Transational } \\
\text { Transformational } \\
\text { Laissez-faire }\end{array}$ & $\begin{array}{l}\text { Different leadership styles have } \\
\text { different impact on followers in terms } \\
\text { of responsibility, momentum, and stress }\end{array}$ \\
\hline $\begin{array}{l}\text { Emotional } \\
\text { intelligence }\end{array}$ & Late 1990s & $\begin{array}{l}\text { Leader's emotional intelligence can } \\
\text { influence the performance of subordinates } \\
\text { more than intellect }\end{array}$ & $\begin{array}{l}\text { Visionary } \\
\text { Coaching } \\
\text { Affiliative } \\
\text { Democratic } \\
\text { Pacesetting } \\
\text { Commanding }\end{array}$ & $\begin{array}{l}\text { The first four types are suitable for } \\
\text { certain project type, while the last two } \\
\text { are toxic }\end{array}$ \\
\hline Competency & $2000 \mathrm{~s}$ & $\begin{array}{l}\text { This is the combination of all the theories, } \\
\text { including traits, personal characteristics } \\
\text { and essential skills as a leader }\end{array}$ & $\begin{array}{l}\text { Engaging } \\
\text { Involving } \\
\text { Coal-oriented }\end{array}$ & $\begin{array}{l}\text { Different leadership can improve } \\
\text { the performance of project if the } \\
\text { appropriate styles have been selected }\end{array}$ \\
\hline
\end{tabular}


The six leadership styles identified are listed in Table 2 alongside their relationship with project type. The last two types are considered as toxic because they have dissonance effect on followers (Goleman et al., 2002).

The competency school absorbs all characteristics of former theories with a group of fifteen leadership competences (Table 2).

This large group of competencies can be concluded into three main groups:

Emotional competencies; Managerial competencies; Intellectual competencies.

With various combinations of competencies, different leadership styles can be achieved to meet the requirement of certain types of project. Since the competencies listed here are available to be learned, so the competency school also prove the accuracy of behavioral or style school theory. Although, through competencies theory, leadership styles such as transactional and transformational can be made, three types of original leadership styles are proposed by Dulewicz and Higgs (2003), which is known as Goal Oriented, Involving and Engaging. Their correlation with every competency is shown in Table 3.

Table 3 clearly illustrates the development of leadership style from the identification of how leadership skills are obtained to the superior competency theory and also compares the link between leadership style and project type at different stages.

\section{Project Success Factors}

To find the relationships, how to make a project successful is reviewed. Morris and Pinto (2007) defined successful project as below:

If the project meets the technical performance specifications and/or mission to be performed and if there is a high level of satisfaction concerning the project outcome among key people in the parent organization, key people on the project team and key users or clientele of the project effort.

It is prevalent to apply critical success factors to assess the success of project. The 10 factors (Baker et al., 1988) listed in Table 4 , are the most acceptable design.

Table 3: Fifteen Leadership competencies in three groups

\begin{tabular}{lll}
\hline $\begin{array}{l}\text { Emotional } \\
\text { Competencies }\end{array}$ & $\begin{array}{l}\text { Managerial } \\
\text { Competencies }\end{array}$ & $\begin{array}{l}\text { Intellectual } \\
\text { Competencies }\end{array}$ \\
\hline Motivation & $\begin{array}{l}\text { Managing } \\
\text { resources } \\
\text { Engaging } \\
\text { Conscientiousness }\end{array}$ & $\begin{array}{l}\text { Strategic perspective } \\
\text { Commication and imagination }\end{array}$ \\
Sensitivity & $\begin{array}{l}\text { Developing } \\
\text { Influence }\end{array}$ & Critical analysis and judgment \\
Self-awareness & Achieving & \\
Emotional resilience & & \\
Intuitiveness & &
\end{tabular}

Source: Dulewicz and Higgs (2003)
However, the leadership is not clearly mentioned here. It is not a coincidence. In the history of success factors, manger's leadership is present rarely. Andersen et al. (1987) proposed a list including project pitfalls, various cautions for project managers, within which leadership is mentioned only one time in the suggestion managerial competence is the standard for project manager selection. The second presence of leadership is in a list of failure factors made by Morris (1988). In the context of life cycle, he claimed that poor leadership is a failure factor during inception, construction and close-out except execution. Despite that some researchers reported that there is a close link between manager's skill and the success of project, but they never treated manager as the critical factor (Lee-Kolley and Loong, 2003). One strategy designed by Turner (1999) for improving the implantation of projects identifies a "seven forces" concept, one force of which is people. The people concept here is explained as the human and many other related things, such as leadership. However, it is still not obvious.

\section{Link of Leadership Style and Project Success}

From the review of project success, it is surprising that the leadership style is not one of the critical success factors, to explain this, Tunrner and Muller (2005) claimed it may be the project managers asked in the studies of ignore the effect of themselves or the impact of the project leader is not measured in these studies. However, it is concluded by various articles that the selection of leadership influences the performance of project (Crawford et al., 2005; Dulewicz and Higgs, 2003). What is more, In Table 5, some research work examining the relationship has been summarized, which obviously implies that there are some certain relationships between leadership and project success. Especially the third study providing that some of the success factors are related to leaderships.

Table 4: Project success factor

\begin{tabular}{ll}
\hline Project Mission & Top Management Support \\
Schedule And Plans & Client Consultation \\
Personnel & Technical Tasks \\
Client Acceptance & Monitoring And Feedback \\
Communication & Troubleshooting \\
\hline
\end{tabular}

Table 5: Studies on the relationship between leadership style and project success

\begin{tabular}{|c|c|c|c|}
\hline $\begin{array}{l}\text { Research } \\
\text { work }\end{array}$ & Leadership style & Results & Methodology \\
\hline $\begin{array}{l}\text { Yang et al } \\
(2011)\end{array}$ & $\begin{array}{l}\text { Transactional } \\
\text { Transformational }\end{array}$ & $\begin{array}{l}\text { Transformational } \\
\text { leadership is } \\
\text { suitable for } \\
\text { project manager }\end{array}$ & $\begin{array}{l}\text { Online } \\
\text { questionnaire } \\
\text { and quantitative } \\
\text { analysis }\end{array}$ \\
\hline $\begin{array}{l}\text { Muller } \\
\text { and Turner } \\
\text { (2007) }\end{array}$ & $\begin{array}{l}\text { Goal-oriented } \\
\text { Involving } \\
\text { Engaging }\end{array}$ & $\begin{array}{l}\text { Appropriate } \\
\text { leadership can } \\
\text { improve project } \\
\text { performance }\end{array}$ & $\begin{array}{l}\text { Interview, } \\
\text { questionnaire } \\
\text { and data } \\
\text { analysis }\end{array}$ \\
\hline $\begin{array}{l}\text { Geoghegan } \\
\text { and Dulewicz } \\
\text { (2008) }\end{array}$ & $\begin{array}{l}\text { Goal-oriented } \\
\text { Involving } \\
\text { Engaging }\end{array}$ & $\begin{array}{l}\text { Identification } \\
\text { competencies } \\
\text { related in the } \\
\text { context of } \\
\text { project manager }\end{array}$ & $\begin{array}{l}\text { Leadership } \\
\text { dimensions } \\
\text { Questionnaire }\end{array}$ \\
\hline
\end{tabular}


To find the mechanism how project success is influenced by leadership style, the nature of leadership is reviewed. Then it is found that leadership is mainly two main concepts, the communication with followers and the direct management of project. So a reasonable cause for the disappearance of leadership in the list of critical success factors is that the project performance is influenced more by teamwork than direct management. The leadership likely impacts project through teamwork. Shamir et al (2000) reported that a good leadership can improve the teamwork. This view is supported by other authors who consider appropriate leadership is a positive factor of teamwork related to communication, collaboration and cohesiveness (Bass, 1990; Yammarino et al., 1998). In Yang's study, a research model (Figure 1) was built to demonstrate the relationship among leadership, teamwork, project success, project type.

When the research is conducted, different combinations of project type and leadership style are studied. The performance of teamwork and project results is correlated to these combinations, which reflect the impact from leadership. As expected, his results indicate that teamwork can be improved by appropriate leadership style in a certain circumstance, namely the project type. Further, the performance of project can benefit from the improved teamwork. Now the hidden relationship has been emerged. A similar model was produced by Muller and Turner (2007). In his research, the leadership style is regarded as independent variables. Project success is the dependent variables and project type is conceptualized as moderating variables. But in his model, teamwork is not considered. Hence, this model is not able to reflect the relationship totally. Geoghegan and Dulewicz (2008) reproduce the category of competencies into two large groups, usability (make project go smooth) and project delivery. Furthermore, the original 15 factors are reduced to 10 most significant competencies, which are listed in Table 6. This table provides an idea of the direct relationship between leadership and project success.

\section{Discussion}

Although project is not a critical factor for project success, the description and analysis above effectively prove that leadership style do influence the project performance. Most critical success factors are influenced or even controlled by project manager, such as project mission, personnel, communication with team members etc. Both the two models described above are not perfect. Since impact from leadership is exerted on teamwork and project success at the same time. From Table 6, it can be

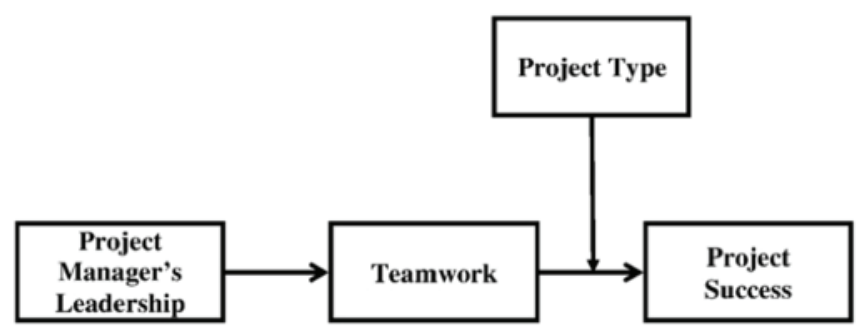

Figure 1: Research model observed that some competencies are related to success factors directly, such as the competency of critical analysis to the factor of trouble shooting. So the direct impact from leadership cannot be neglected. Based on these two models and information gathered from literature review, a system dynamic model was built by the author to illustrate the relationship between leadership style and project success.

This model clearly demonstrates the relationships within a simple project system. An unfamiliar project type is negative to the teamwork. Then this effect can reduce teamwork's positive contribution to achieving success. The project type also can negatively affect project success directly. However, if an appropriate leadership style is selected, the negative effect from the project type will be weakened by leader's reasonable management with corresponding competencies. With such a model, it is then possible to study both the direct and indirect degree of impact from leadership. The results of the comparison of these two impacts can offer an idea for the design of new critical project success factors.

\section{Conclusion}

The literature review of three aspects knowledge reflects that leadership is critical to project success. Although leadership or manager is rarely included in the project success factors, it influences the performance of project through various patterns, like the collaboration of teamwork, management of source, communication with both followers and clients. Generally, these patterns can be grouped into two ways: direct way and indirect way. According to the mechanism in Figure 2., the two ways are described as below:

1. Direct: Appropriate leadership can benefit project success with corresponding competencies.

\section{Table 6: New competencies}

\begin{tabular}{ll}
\hline Usability & Project delivery \\
\hline Managing resources & Managing resources \\
Empowering & Self-awareness \\
Empowering & \\
Developing & \\
Motivation & \\
Critical analysis & \\
Influencing & \\
Sensitivity & \\
\hline
\end{tabular}

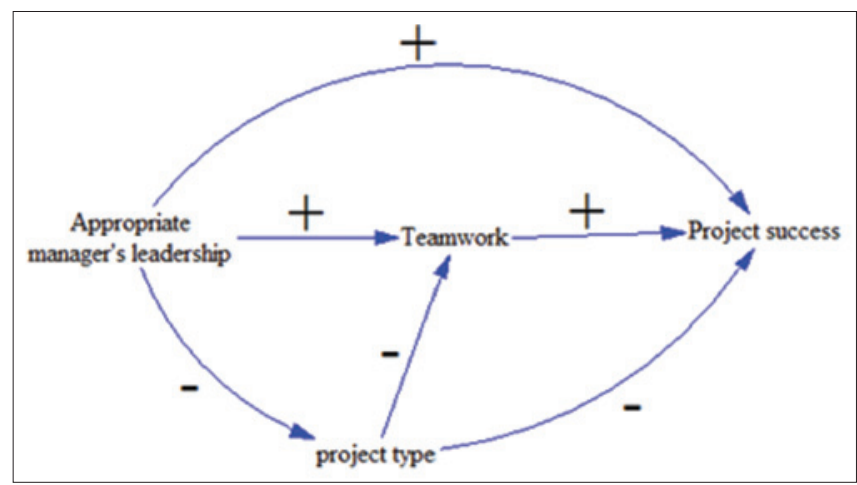

Figure 2: Simple system dynamic model of project management 
2. Indirect: Appropriate leadership improves teamwork, which can help achieve successful project.

The two patterns namely are the links of leadership style and project success. In addition, the project type need special care, the positive influence from leadership to project success depends on whether appropriate leadership style has been selected according to project type. Further studies are required to prove the view point.

\section{References}

Andersen, E. S., Grude, K. V., Haug, T., \& Turner, J. R. (1987). Goal directed project management, London: Kogan Page/Coopers \& Lybrand.

Baker, B. N., Murphey, P. C., \& Fisher, D. (1988). Factors affecting project success. In D. I. Cleland \& W. R. King (Eds.), Project Management Handbook (2nd ed.). New York: Van Nostrand Reinhold.

Bass, B.M., Avolio, B.J., 1990. Transformational Leadership Development: Manual for the Multifactor Leadership Questionnaire. Consulting Psycholo- gists Press, California.

Crawford, L.H., Hobbs, J.B., Turner, J.B. (2005). Project categorization system: aligning capability with strategy for better results. Upper Darby (PA): Project Management Insitute.

Dionne, S.D., Yammarino, F.J., Atwater, L.E., 2004.Transformational leadership and team performance. Journal of Organizational Change Management 17 (2), 177-193.

DuBrin, A.J., 2004. Leadership Research Findings, Practice, and Skills, $4^{\text {th }}$ ed. Houghlon Mifflin Company, Indianaphlis.

Dulewicz, V., \& Higgs, M. J. (2003).Design of a new instrument to assess leadership dimensions and styles. Henley Working Paper Series HWP 0311. Henley-on-Thames, UK: Henley Management College.

Geoghegan, L., \&Dulewicz, V. (2008). Do project managers' leadership competencies contribute to project success Project management journal, 39(4), 58-67.

Goleman, D., Boyatzis, R.E., McKee, A. (2002) The new leaders. Harvard Business School Press. Cambridge (MA).

House, R. J. (1971). A path-goal theory of leader effectiveness. Administrative Science Quarterly, September, 321-338.

Morris, P. W. G. (1988). Managing project interfaces. In D. I. Cleland, \& W. R. King (Eds.), Project Management Handbook ( $2^{\text {nd }}$ ed.). New York: Van Nostrand Reinhold.

Muller, R., \& Turner, J. (2007). Matching the project manager's leadership style to project type. International Journal of Project Management. 25(1), 21-32.

Peter Morris, Jeffrey K. Pinto., 2007. The Wiley Guide to Project, Program, and Portfolio Managemen.Wiley and Sons, New Jersey.

Shamir, B., Brainin, E., Zakay, E., Popper, M., 2000. Perceived combat readiness as collective efficacy: individual-and group-leve/ analysis. Military Psychology 12 (2), 105-119.

Turner, J. R. (1999). The handbook of project-based man- agement: Improving the processes for achieving strategic objec-tives. London: McGraw-Hill.

Turner, J. (2005). The project manager's leadership style as a success factor on projects: A literature review. Project management journal.

Wang, E., Chou, H.W., Jiang, J., (2005). The impacts of charismatic leadership style on team cohesiveness and overall performance during ERP implementation. International Journal of Project Management 23 (3), 173-180.

Yang, L.-R., Huang, C.-F., \& Wu, K.-S. (2011). The association among project manager's leadership style, teamwork and project success. IPMA, 29(3), 258-267.

How to Cite: Jiang J. 2014. The Study of the relationship between Leadership Style and Project Success American Journal of Trade and Policy, 1, 51-55.

Source of Support: Nil, Conflict of Interest: None declared. 